\title{
Relationship between Reflective Practices of Teacher Educators and the Creativity of the Prospective Teachers \\ ${ }^{1}$ Dr. Syed Asad Abbas Rizvi, ${ }^{2}$ Shah Faisal
}

\begin{abstract}
The main focus of the study was to find out the relationship of reflective practices and creativity of prospective teachers at university level. The objectives of the study were; to identify the types of reflective practice of teacher educators; to identify the frequency of reflective practice of teacher educators; to determine the creativity level of the prospective teachers; and to find out the relationship of reflective practices of teacher educators with creativity of prospective teachers. The study is survey by method and correlational by purpose. Two questionnaires were used for the purpose of data collection. One questionnaire was tailor made and the other was a custom made questionnaire. Each questionnaire consisted of 25 questions and was scored for the use of establishing the relationship between the two variables (i.e., reflective practice of teacher educators and creativity of the prospective teachers). The population of the study consisted of all the B.Ed. students in the six public sector universities of Khyber Pakhtunkhwa Province of Pakistan out of which a sample of 220 B.Ed. students was taken through proportionate random sampling technique for the collection of data. The findings of the study reveal that teacher educators carry out various reflective practices during their instruction with a variation in their frequencies. The study also shows a strong, positive and significant relationship between the reflective practices of teacher educators and creativity of prospective teachers. The teacher educators, therefore, might concentrate more on new and innovative forms of reflective practices enabling the prospective teachers to discharge their duties in future efficiently and effectively.
\end{abstract}

Keywords: Reflective practices. Teacher Educators, Prospective Teachers

\section{Introduction}

Teacher education is aimed at to improve learning of the learners in the schools and develop in them the ability to cope with daily life problems. This can be achieved by adopting effective approach from the spectrum of different approaches to the teaching practices, for example, instructional approach,

\footnotetext{
${ }^{1}$ Assistant Professor, Department of Education, Faculty of Social Sciences, International Islamic University Islamabad Pakistan Email: drasad.rizvi@iiu.edu.pk

2 PhD Scholar, Department of Education, Faculty of Social Sciences, International Islamic University Islamabad Pakistan
} 
pragmatic approach and exploratory approach. Teaching creatively is one of the core ability of teacher.

In recent years, teacher education faces new areas of teaching creatively and professional development. Wideen, Grimmett and Andrews (2002) contends that professional development has to be made in three different perspectives; firstly, the knowledge transfer and skill development; secondly, the reflective practices; and thirdly, the soico-political-cultural change. Teachers' creativity and productivity has direct bearing on learners' creativity and productivity. Teachers' productivity and creativity must be developed through different means like reflective practices during their training period (Chilvers, 2005). These practices engage participants of the teaching-learning process in a "cycle of thought and action based on professional experience" (Weil, 2004, p. 4).

Reflective teaching practices enable individuals to learn through their wideranging experiences throughout their life in general, and in the profession in particular in order to improve themselves. According to Osterman \& Kottkamp (1993, p.19): Reflective practice is viewed as a means by which practitioners can develop a greater level of self-awareness about the nature and impact of their performance, an awareness that creates opportunities for professional growth and development.

Creativity is viewed in two perspectives; as historical new or something new in personal sense. In historical creativity the work is relatively rare whereas in personal creativity, the individual irrespective of the others' view and response to it considers the work new. Csikszentmihalyi (1996) has defined creativity in terms of rare individuals who have been judged by others, to have significantly creative, often domain-changing contributions, whereas Craft (2001) has focused on creativity in a general population, with respect to education.

The empowerment of individuals to survive in the novel and challenging situations of life can be achieved, if the teachers are capable enough to do so. Whatever has been done so far or has been planning to be done, the main focus is the effective learning of the individuals at the receiving end in the instructional programme (Woolfolk, 2004). The behaviour of teachers, their instructional methodology, their vision of educating new generation, their approach to teaching profession, their awareness of the instructional situation as well as knowledge of the individual differences of the learners mostly determine the effectiveness of the process of education (Phan,2015).

The purpose can be served if the teacher education programmes focus on such techniques, approaches and methods that train the prospective teachers and even the in-service teachers accordingly. The practice of teacher educators persuades the prospective teachers while they are teaching in schools. They do 
practice what they have received during their training programmes (Richards \& Farrell, 2005).

Reflective practice is one such innovative approach to the art and science of instruction that has been in vogue since the mid of second half of the previous century in various applied fields. Individuals in the field of teaching acknowledged its effectiveness and hence adopted it at every level (Schon, 1987). The study identifies the reflective practices of teacher educators and their frequency. It also finds out the relationship between the reflective practices of teacher educators and the creativity of prospective teachers (Osterman \& Kottkam, 1993).

There are a number of studies (Phan, 2015; Palmer et al, 2008; Ferede, \& Gorfu, 2008; Ross, 2011; Donnelly, 2007) that highlight the effects of reflective teaching practices on the academic performance and teaching-learning process; however little has been done so far to probe into the linkage between reflective teaching practices and the creative thinking and creativity.

\subsection{Statement of the Problem}

Teaching is a complex phenomenon which deals with the management of diverse situations and people with individual differences. So the development of creativity in the prospective teachers enables them to manipulate the situation in future and address adequately the diversified nature of human beings as learners at the school in the days to come. Reflective practice in teaching is an important aspect of instructional process and can be helpful in the development of creativity. The study identifies the reflective practices of teacher educators and their frequency. It also finds out the relationship between the reflective practices of teacher educators and the creativity of prospective teachers. So the problem to investigate was, to find out the relationship between reflective practices of teacher educators and creativity of prospective teachers.

\subsection{Objectives of the Study}

The objectives of the study were to:

1. identify the types and frequency of reflective practices of teacher educators.

2. determine the creativity level of the prospective teachers.

3 . find out the relationship between the reflective practices of teacher educators with creativity of prospective teachers.

\subsection{Research Question}

The basic research question was "What is the relationship between the reflective practices of teacher educators and creativity of the prospective teachers?" 


\subsection{Significance of the Study}

The study would be significant for many stake holders in following aspects;

1. It is significant for teachers as it allows to give more time to students to think and explore in their own way.

2. It is significant for parents to understand that there is always an alternative way of teaching kids at home.

3. The study would be significant for school administrators to make their institution a place of learning with happiness.

4. In order to make a classroom creative, a teacher too has to be creative, to some extent. Creative teaching can only be a part of a classroom if the teacher presiding over is an ingenious individual. A teacher who is creative enough to be part of the innovative classroom can design exciting new lessons, motivate the right classroom environment required for students to showcase their innovative minds. So this study would be significant for teachers as they also turn into creative persons.

\section{Models of Reflective Practices}

\section{Review of Literature}

Reflective practices have been developed and implemented by experts in different ways. They have devised various models for it. Here we will discuss some most important models of reflective practices described in the literature are presented below:-

\section{Jasper's ERA Cycle of Reflective Practice}

Reflective practice is primarily based on the past experiences of the practitioners "to understand and develop their practice" (Jasper, 2003, p. 2) as these experiences are the basic stuff for one's further progress. Jasper (2003) presents the ERA Cycle of Reflective Practice (see figure 1), which consist of three basic components. The process is not once for all, but continues unlimitedly as the first round of the process completes, which provides stuff (experience) for the next round and thus "the experience itself has been transformed, making it into a different experience" (Jasper, 2003, p.3) forming a spiral which can be seen in figure 2.2 . 


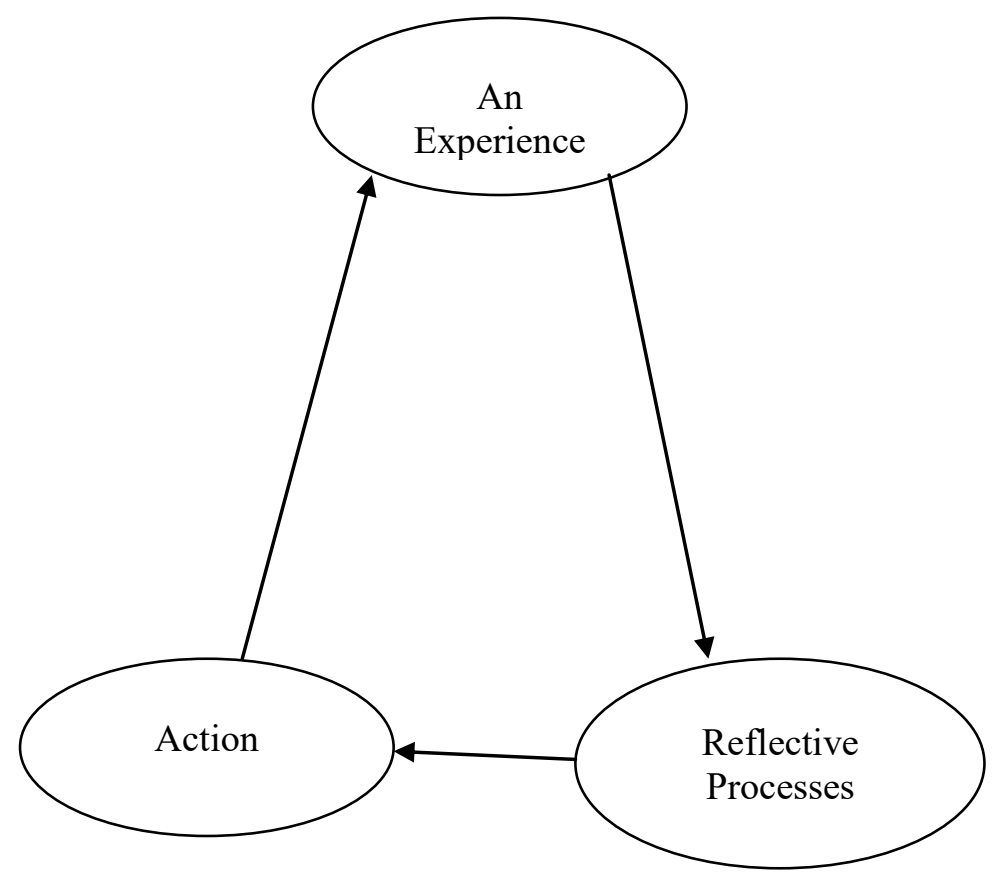

Fig 2.2-The ERA cycle of Reflective Practice 


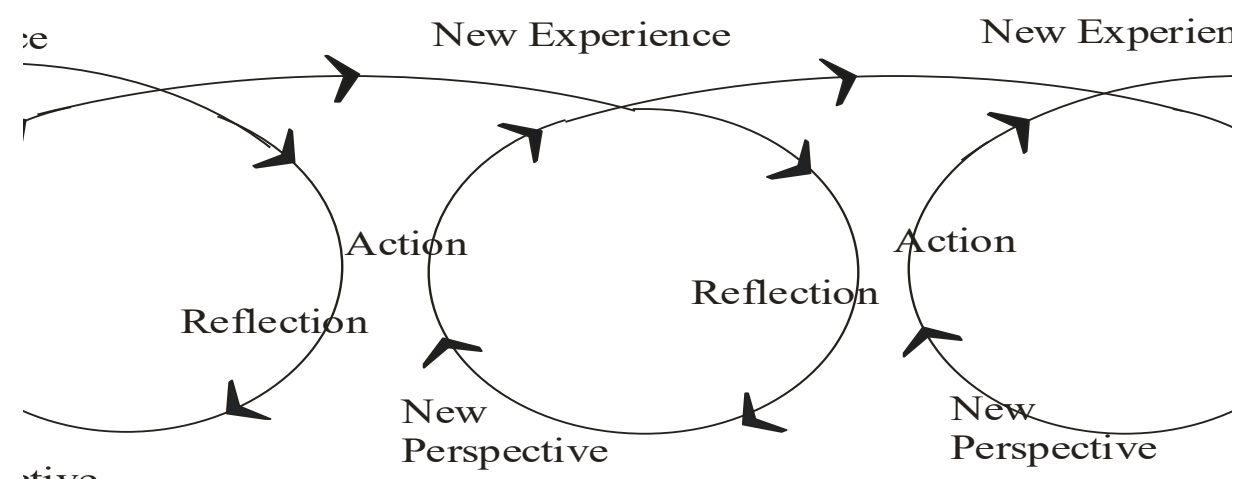

FIG. 2.2: Reflective Spiral

\section{Johns' Model of Structured Reflection}

Johns (2006) attempted to make the reflective practices more easy and comprehensible for the practitioners, and put forward a framework for reflective practice in Nursing. His model of Structured Reflection appeared in the early part of the last decade of $20^{\text {th }}$ century as it was "first constructed in 1991" (Johns, 2006, p. 42), which has gone "through many developments and presentations" (Jasper, 2003, p. 84) that continued till the last moment of the first decade of $21^{\text {st }}$ century (Feiman\&Beasely, 2007). In 1994, it was presented in a simple cue questions form dividing into five different sections that included description of the experience; reflection; influencing factors; could I have dealt with the situation better?; and learning.

The model of Structured Reflection is not a checklist but the cue questions are meant for suggestion (Hall, 1997), which provides a very simple and easy understanding for the new practitioners. It is "a framework for challenging 'unexamined norms' and 'habitual' practice; for 'interpret[ing] the subjective experiences', for 'project[ing] the effects of nursing actions', and for 'becoming a certain sort of person" (Johns, 2006; Feiman, 2001) that can put into operation of his/her own past experience while performing new actions during their professional life. 


\section{An Overview of Available Literature}

The review of the available literature related to the study reveals that the concept of reflective practice was, although introduced by John Dewey on the onset of twentieth century, however, it has its roots in the works of ancient philosophers like Socrates, Plato and Aristotle (Zeichner, 1981) The study of literature shows that at all ages, reflective practice was used with different and specific nomenclature. Nonetheless, as an independent instructional strategy, reflective practice got attention among the academicians and practitioners of other applied fields in the last quarter of the previous century. Since then a number of research studies were carried out about the practice and its implications on various aspects of the academic performance in the various fields (Chilvers, 2005).

Reflective practice is an effective instructional strategy that is based on the practitioners' experiences. It provides for the utilization of known in a situation that is novel and unknown or abstract. It can be made during or after the activity or instruction as Schon states, but before the activity it would be more result oriented and productive as compared to the earlier ones (Bolton, 2010). The practitioners can use either of the modes of reflection such as contextual, dispositional or experiential, according to the situation.

For the benefit and ease of the practitioners, different models of reflective practice are available. The different forms and types of reflective practice can be helpful to the practitioner in order to practice reflective activities (Wideen, Grimmett \& Andrews, 2002). They may include, active learning, action research, collaborative learning, team teaching, micro teaching, storytelling, unit review, course review, programme review, brainstorming, blogging, individual and group projects, critical incident analysis, clinical supervision, lesson report and many more (Bolton, 2010).

Reflective practice is an evidence-based inquiry that is meant for the attainment of aims and strives for outcomes through judgment and insight takes place in a cyclic process (Schon, 1996). It demands collaboration, cooperation, responsibility, wholeheartedness, open-mindedness and creative mediation from the practitioners (Zeichner, 1994). It provides thinking opportunity to the practitioners in a new situation, whenever arise (Adair, 2007; Schon, 1983).

Creativity is generated and flourished though various means, if desired so. It is ability, an attitude, a habit and a process of doing things in a different and innovative way (Harris 1998). It is looked upon in different manners, such as process, product, person, place, persuasion, and potential. It is intangible and can only be recognized by the characteristics a person possesses, when $\mathrm{s} / \mathrm{he}$ is creative. These include ability to solve problem, curiosity, humour, fluency, 
tolerance, flexibility, open-mindedness, imaginative, witty, positivity, adventurous, risk-taking, optimism and reflectivity (Craft, 2001).

\section{Research Methodology}

Research method adopted in the study is briefly discussed below.

\subsection{Type of the Study}

The study was a survey by design and correlational by purpose.

\subsection{Research Instruments}

Two questionnaires were used for the purpose of data collection.

1. A tailor-made questionnaire was used for identifying the type of reflective teaching practices and their use by the teacher educators.

2. A custom made questionnaire was used for calculating the creativity quotient (CQ) of the prospective teachers. The questionnaire was a quiz adopted from ("QuizMoz", 2016). The publisher encourages using the quiz as the site states, "Go ahead and find out what you know about yourself and the world around you" (www.quizmoz.com/quizzes/personality-Test/c/Creativity-QuotintTest.asp, para 1).

\subsection{Population of the Study}

Population of the study comprised of the prospective teachers enrolled in Bachelor of Education (B. Ed.) programme in the Departments/Institutes of Education in universities of Khyber Pakhtunkhwa Province of Pakistan. The total population of the study consisted of 512 prospective teachers in six universities of the Province. The list of universities and the students, enrolled there in Bachelor of Education programme, is given in Table 1.1.

Table No. 1.

Target Universities \& number of their enrolled B.Ed. students

No. Universities No. of B.Ed.

Students

\begin{tabular}{clc}
\hline 1 & University of Peshawar & 253 \\
2 & Gomal University, D.I. Khan & 127 \\
3 & Hazara University, Mansehra & 68 \\
4 & University of Malakand, Chakdara & 24 \\
5 & University of Science \& Technology, Bunnu & 15 \\
6 & Abdul Wali Khan University, Mardan & 25 \\
\hline Total & & 512 \\
\hline
\end{tabular}




\subsection{Sample of the Study}

The proportionate random sampling technique was used for the selection of sample size. The total sample size consisted of $220(43 \%)$ prospective teachers of different universities of Khyber Pakhtunkhwa Province of Pakistan.

\subsection{Scoring of the Research Instruments}

The instruments were scored by assigning each option a particular score ranging from 0-4 for identifying the relationship between the two variables.

\subsection{Data Collection}

The data were collected through personal administration of questionnaires by the researcher in approachable areas, whereas postal correspondence was used for the collection of data from the distant areas of the province for variety of reasons such as security situation of the area, time and resources, etc.

\subsection{Data Analysis}

The univariate data were analyzed by using percentages whereas bivariate data was analyzed by using Pearson Product-Moment Correlation Method.

\section{Findings of the Study}

The findings of the study are divided in three parts, as present below:

\section{Types and Frequency of Reflective Practice}

The findings concerning the frequency and types of reflective practice were as follows:

1. The $41.99 \%$ prospective teachers reported that learning activities are used by the teacher educators most often whereas $39.78 \%$ viewed that they carry out learning activities mostly during their instruction.

2. The $39.23 \%$ prospective teachers believe that the unit review is frequently made by their teachers while $28.18 \%$ think that teacher educators go for it mostly and $23.20 \%$ consider that the teacher educators do unit review sometime while $5.52 \%$ think that they rarely do it.

3. Following are the types of Reflective practices used by teacher educators as perceived by prospective teachers;

a) Review of courses

b) Story telling

c) Record Keeping of classroom activates by themselves and by students

d) Group assignment/Project

e) Completely monitor and guide the group-activities of the learners given by teacher

f) Allow to check their fellow work 
g) Start new topic with making questions

h) End their discussion in a query for the learners

i) Engage with critical friends/colleagues in the classroom activities, for the improvement of instructional procedures

j) Mind mapping activity is often carried out by teacher educators

k) Use of problem solving methods during their instruction

1) Often acknowledge the mistakes before the students in the class that were committed during instruction

m) Assign individual writing assignments to the learners

n) Writing self-reports regarding different things what the learners thought interesting and mention worthy by the teacher educators

o) Ask the students to present different topic before the class

p) Encourage to ask critical question during their instruction by teacher educators

q) Reinforce students' views and comments

r) Conduct Collaborative Action Research

s) Use of AV Aids and real examples

\section{Creativity}

The findings regarding creativity level were as follows:

1. The average creativity quotient for the students of University of Peshawar was 70.72. The average creativity level calculated for the students of Hazara University, Mansehra was 71.2

2. The average creativity level point for the students of University of Malakand was 73.57 .

3. The average creativity quotient for the students of University of Science and Technology, Bannu was 80.00.

4. The average creativity quotient for the students of Gomal University, D. I. Khan was 64.58.

5. The average creativity level of the students at Abdul Wali Khan University, Mardan was 74.62.

6. The overall average of creativity quotient for the B.Ed. students at different universities was 70.08 .

\section{Relationship between Reflective Practice and Creativity}

The findings about the relationship between reflective practice and creativity were as follows: 
1. The relationship between reflective practice and creativity level is positive and significant at the University of Peshawar as the calculated $r$ value (i.e. 0.40576131 ) is greater than that of table value of $r$ (i.e. 0.205) at $\alpha=0.05$.

2. The relationship between reflective practice of teacher educators and creativity of the prospective teacher at the Hazara University, Mansehra is positive and significant as the calculated value of $r$ (i.e. 0.52399471) is greater than that of the table value of r (i.e. 0.3493) at $\alpha=0.05$.

3 . The calculated value of $r$ is 0.85411183 , which is greater than that of the table value of "r" that is 0.7545 at $\alpha=0.05$ for University of Malakand, Chakdara, Lower Dir, so relationship is strong, positive and significant.

4. The relationship between reflective practice and creativity is positive, significant and strong as the calculated value of $r=0.97448058$ is greater than the tabulated value of $r=0.8783$ at 0.05 level of significance for the University of Science and Technology, Bannu.

5. At Gomal Univeristy, D. I. Khan, the relationship between the reflective practice and creativity level is positive and significant as the calculated value of $r=0.54403733$ is greater than its table value 0.2875 at the level significance 0.05 .

6. The $\mathrm{r}=0.84703433$ is greater than the table value 0.7067 at $\alpha=0.05$ for Abdul Wali Khan University, Mardan that show as positive, significant and strong relationship between reflective practice and creativity.

7. Over all the relationship between the reflective practice of teacher educator is positive, significant and strong as the calculated $\mathrm{r}$ is 0.53318639 that is greater than the table value of $r=0.1946$ at the probability level of 0.05 .

\section{Discussion}

The discussion on the study was carried out according to the objectives of the study as under

\section{Types and Frequency}

It was found that there are different types of creative practices with different frequencies. Henriksen (2011) emphasized on variety of creative teaching techniques. Similarly David \& Milgram, (2006) stated that it is difficult to make a list of creative techniques and its use as it depends upon the nature of subject, teacher's expertise, content and ability of learners (David \& Milgram, 2006). It indicates that no matter what the technique used and how many times it was used, the focus may be on creativity of stakeholders

According to Cowley (2005), Creativity, as can be developed by different means, similarly has adversely affected by many factors. These factors include undue criticism, product bias, neglecting brainstorming, convergent practices, 
negative attitude, lack of motivational environment, problem hoarding, person's feelings about creativity, fear, lack of experience, lack of techniques, overreliance on techniques and outsourcing change.

\section{Creativity Level}

The second group of findings was related to the creativity of the prospective teachers. It was found that they have a good creativity level with an average more than 70. Pink (2005) stated that anything above 50 is considered as a good level of creativity. On the other hand Mishra, Koehler, \& Henriksen (2011) stress that creativity level may be at least 70 to be a good creative person. In this research, the minimum level of the creativity was found to be 70 . This means that most of the prospective teachers were creative, but there is very little room in our educational system that they express and excel their creativity.

\section{Relationship between Reflective Practices and Creativity Level}

The third and the main objective of the research was related to find out the relationship between reflective practices and creativity level. A strong relationship was found in this regard. Root-Bernstein (2003) argued that there is a close relation between creativity and reflective practices. The same results were discussed by Mishra, Henriksen and Bolton (2010). They studied many creative teachers using different tools of research and concluded that teachers who were perceived as creative are those who also carried out different reflective practices.

\section{Conclusions}

On the basis of research findings, the following conclusions were made:

1. The teacher educators realize and recognize the effectiveness of reflective practice and they do their level best to train and educate the individuals for the education of new generation of the society. They generally use different forms of reflective practice during their instruction. The types/forms that they use include storytelling, unit review, brainstorming, mind mapping, critical enquiry, learning activities, group assignment, mentoring, students' presentations, referring daily life examples, course review, journal keeping, peer observations, engaging critical friends, problem solving, self-accounting, individual writing assignments, self-reports, writing account of life experiences, reinforcement, action research, collaborative action research, using audio-visual aids. (Objective No. 1)

2. The frequency of different forms of reflective practice practiced by teacher educators was different. 'The teacher educators regularly use storytelling, unit review, brainstorming, mind mapping, critical enquiry for the intellectual development of their learners. They most often conduct learning activities, group assignment, supervising group work, students' presentations and 
referring daily life examples to make clear the concepts to their learners and ensure effective learning. (Objective No. 2)

3. Teacher educators go less frequently for course review, journal keeping as well as students' journal keeping during their instruction. They also do not work out the peer observations, engaging critical friends, problem solving, self-accounting to the level it need to be addressed. The procedures of individual writing assignments, self-reports, writing account of life experiences, reinforcement, limited action research, collaborative action research, using audio-visual aids are typically practiced by the teacher educators. (Objective No. 2)

4. The creativity quotient of the students at different universities individually as well as the overall creativity quotient shows high level of creativity. The average point of creativity quotient was higher than the mean score. (Objective No. 3)

5. The relationship between the reflective practice of teacher educators and the creativity of prospective teachers was highly significant, strong and positive. Both, the reflective practice and creativity have a direct relationship between themselves. (Objective No. 4)

\section{Recommendations}

1. In the light of the research findings and conclusions, the following recommendations were made:

2. The teacher educators may concentrate on the new and more effective reflective practice during their instruction, so that their learners are trained in a better way for the discharge of their future responsibility of the nation building.

3. The evaluation procedures of the teacher education programmes may be made so innovative and dynamic that the teacher educators should not follow the stereotype methodology and materials during their instruction.

4. Teachers' reflective practice requires creativity on their part. In future, research studies may be carried out on the effects of teachers' creativity on their reflective practices during their instruction at various levels.

5. Individual differences matter a lot, particularly gender differences in instructional

6. Practices; therefore, research studies may be conducted on the basis of genderbased difference in reflective practice and effects on the creativity of their heterogeneous-gender learners. For instance; A study of the gender role in the effectiveness of reflective practices on the creativity of learners 
7. Last but not the least; reflective practice journal may be introduced in the institutions of teacher education. And research studies may be carried out on the effectiveness of reflective practice journals.

\section{References}

Adair, J. (2007). The Art of Creative Thinking: How to Be Innovative and Develop Great Ideas. London: Kogan Page Limited.

Bolton, G. (2010). Reflective Practice: Writing and Professional Development $\left(3^{\text {rd }}\right.$ Ed). London: Sage Publications Ltd.

Chilvers, D. (2005). Rethinking Reflective Practice in the Early Years. In K. Hirst \& C. Nutbrown (Eds.), Perspectives on Early Childhood Education: Contemporary Research (pp.163-178). London: Trentham Books Limited.

Cowley, S. (2005). Letting the Buggers be Creative. London: Continuum International Publishing Group.

Craft, A. (2001).Little 'C' Creativity. In A. Craft, B. Jeffrey, \& M. Leibling, (Eds.).Creativity in Education. London: Continuum International.

Csikszentmihalyi, M. (1996).Creativity: Flow and the Psychology of Discovery and Invention. New York: Harper Collins.

David Ovitch, N., \& Milgram, R. M. (2006).Creative thinking as a predictor of teacher effectiveness in higher education. Creativity Research Journal, 18(3), 385-390.

Donnelly, R. (2007). Perceived Impact of Peer Observation of Teaching in Higher Education. International Journal of Teaching and Learning in Higher Education, 19(2), 117-129.

Ferede, T. \& Gorfu, M. (2008). The Effect of Learning Log on the Academic Performance of University Students: The Case of Psychology Second Year Students in Jimma University. Ethiopian Journal of Education \& Science, 3(2), 1-10.

Feiman-Nemser, S. (2001). From Preparation to Practice: Designing a Continuum to Strengthen and Sustain Teaching. Teachers College Record, 103(6), 1013-1055. http://dx.doi.org/10.1111/0161-4681.00141

Feiman-Nemser, S. \& Beasley, K. (2007) .Discovering and Sharing Knowledge: Inventing a new role for cooperating teachers. In: CarrolL, D. et al. (Ed.). 
Transforming Teacher Education: reflections from the field ( pp. 139160).Cambridge, MA: Harvard Education Press.

Hall, S. (1997). Forms of Reflective Teaching Practice in Higher Education. In R. Pospisil \& L. Willcoxson, (Eds.), Learning Through Teaching (pp.124-131). Proceedings of the 6th Annual Teaching Learning Forum, Murdoch University, February 1997. Perth: Murdoch University. http://lsn.curtin.edu.au/tlf/tlf1997/hall1.html retrieved on 22/02/2011

Harris, R. (1998). Introduction to Creative Thinking.Virtualsalt.com. Retrieved 24 February 2011, from http://www.virtualsalt.com/crebook1.htm

Henriksen, D. (2011). We teach who we are: Creativity and trans-disciplinary thinking in the practices of accomplished teachers. (Doctoral Dissertation). Retrieved from ProQuest

Jasper, M. (2003).Beginning Reflective Practice. Cheltenham: Nelson Thornes Ltd.

Johns, C. (2006). Engaging Reflection in Practice: A Narrative Approach. Oxford: Blackwell Publishing Ltd.

Johns, C. (2009). Becoming Reflective Practitioner ( $3^{\text {rd }}$ Ed.). Oxford: WileyBlackwell.

Mishra, P., Koehler, M. J., \& Henriksen, D. (2011). The seven trans-disciplinary habits of mind: Extending the TPACK framework towards 21 st century learning. Educational Technology, 11(2), 22-28.

Osterman, K.F. \& Kottkamp, R.B. (1993).Reflective Practice for Educators. Improving Schooling through Professional Development. Newbury Park, Ca: Corwin Press.

Palmer, S. Holt, D. \& Bray, S. (2008). The Learning Outcomes of an Online Reflective Journal in Engineering. Ascilite Melbourne Proceeding, 724732.

Posted at http://www.ascilite.org.au/conferences/melbourne08/procs/palmer.pdf retrieved on 23/07/2011

Phan, H. P. (2015). Reflective Thinking, Effort, Persistence, Disorganization, and Academic Performance: A Mediational Approach. Electronic Journal of Research in Educational Psychology, 7(3), 927-952.

Pink, D. H. (2005). A whole new mind. New York: Riverhead Books 
QuizMoz.(2011). Quizmoz.com. Retrieved 5 March 2011, from http://www.quizmoz.com/quizzes/Personality-Tests/c/CreativityQuotient-Test.asp

Richards, J. C. \& Farrell, T. S. C. (2005).Professional Development for Language Teachers: Strategies for Teacher Learning. Cambridge: Cambridge University Press.

Root-Bernstein, R. S. (2003). The art of innovation: Polymaths and the universality of the creative process. In L. Shavanina (Ed.), International handbook of innovation, (pp. 267-278), Amsterdam: Elsevier

Ross, J. (2011). Traces of Self: Online Reflective Practices and Performances in Higher Education. Teaching in Higher Education, 16(1), 113-126

Schön, D. A. (1983) The Reflective Practitioner: How Professionals Think in Action, London: Maurice Temple Smith.

Schön, D. A. (1987).Educating the Reflective Practitioner: Toward a New Design for Teaching and Learning in the Professions. San Francisco: Jossey-Bass Publishers.

Schön, D.A. (1996). Educating the Reflective Practitioner: Toward a New Design for Teaching and Learning in the Professions. San Francisco: Jossey-Bass, Inc

Weil, D. (2004). Values and Dispositions of Critical Thinking: Developing Habits of Mind as Moral Commitments to Thought. In J. L. Kincheloe, \& D. Weil, (Eds.), Critical Thinking and Learning: An Encyclopedia for Parents and Teachers (p.485-488). Westport, CT: Greenwood Press.

Wideen, M., Grimmett, P., \& Andrews, I. (2002). International Teacher Education: From Dilemmas to Principles of Action. In E. Thomas, (Ed), Teacher Education: Dilemmas and Prospects (pp. 111-122). London: Kogan Page Limited.

Woolfolk, A. (2004). Educational Psychology ( $9^{\text {th }}$ Ed.). New Delhi: Dorling Kindersley (India) Pvt. Ltd.

Zeichner, K. (1981). Reflective teaching and field-based experience in teacher education. Interchange, 12(4), 1-22. doi: 10.1007/bf01807805.

Zeichner, K. (1994). Research on teacher thinking and different views of reflective practice in teaching and teacher education: Rutledge. 